Włodzimierz Kluciński

ORCID: https://orcid.org/0000-0002-0187-2463

Warsaw University of Life Sciences, Poland

\title{
John Paul II - an Honoris Causa Doctor of the Warsaw University of Life Sciences
}

A unique distinction in more than 200 years' history of the Warsaw University of Life Sciences was the receipt of an honourable doctorate degree awarded to the Holy Father John Paul II by our university 18 years ago.

The inspiration to award John Paul II withan honoris causa doctorate was my meeting, as the rector of the university, with the Holy Father on 30 August 2001 in Castel Gandolfo within the audience for members of the Conference of Rectors of Academic Schools in Poland, attended also by the late Bishop Tadeusz Pieronek, the Rector of the Pontifical Academy of Theology in Cracow (now the Pontifical University of John Paul II in Krakow).

After my return home, at the beginning of October, I shared my reflections with His Eminence Cardinal Józef Glemp and the Papal Nuncio to Poland Archbishop Józef Kowalczyk. I found courage to put forward my proposals during these conversations. The first step was taken on 16 October 2001 when I wrote a letter to the Holy Father, requesting him to accept an honorary doctorate from our university and sending him best wishes on the occasion of the $23^{\text {rd }}$ anniversary of the beginning of his pontificate. I handed this letter in person to Archbishop Józef Kowalczyk.

I received oral information on the Holy Father's approval of my request from the Apostolic Nuncio on 11 November 2001 - National Independence Day. On 27 November I got a letter from the Secretary of State, signed by Archbishop Leonardo Sandri, in which he stated that the Holy Father had acceded to my request, taking into account the historic and cultural tradition of our university. The Pope's approval triggered the university proceedings aimed at awarding the degree. They commenced from taking a resolution by the University Senate, 
chaired by me, on waiving the appointment of the doctorate reviewers. Then we held a common sitting of the Boards of all eleven faculties of the university, at which a resolution was passed to filea petition to the Senate to award the honorary doctorate.

An honoris causa doctorate was conferred to the Holy Father by the University Senate at its sitting on 17 December 2001. At the same time, the Senate voted in favour of the content of the honorary doctorate diploma, presented by me, and appointed my humble person as a doctoral advisor.

While awarding an honoris causa doctorate to the Holy Father, as a single university of agriculture in Poland, the academic community wanted to express its gratitude for the Holy Father's enormous contribution to building the civilization of love, in particular thanking him for:

- his outstanding merits in the field of uniting all nations into one common world family despite religious or political divisions;

- showing academic milieus the ways leading to learning the truth and the need of a dialogue between intellectual cognizance and faith;

- showing the ways of the competent use of the progress of civilization, particularly with respect for human life;

- his teaching addressed to young people of the whole world, pointing at the need of life in love and truth;

- his teaching whose content is farm life and work;

- taking great care for rural Poland and people living there;

- strengthening families with the truth of the Gospel and standing up for the weakest; and

- empathizing with problems of Polish society and acting for the good of the Polish cause.

After letter and telephone arrangements concerning the course of the ceremony, the graduation took place on 11 January 2002 in Clementine Hall at the Vatican. 109 representatives of the academic community of the Warsaw University of Life Sciences, together with members of "Promni", the university folk dance ensemble, arrived at the Holy See for the meeting with the Holy Father. The meeting was also attended by Hanna Suchocka, the Polish ambassador to the Holy See.

The first point of the ceremony was my laudation. 


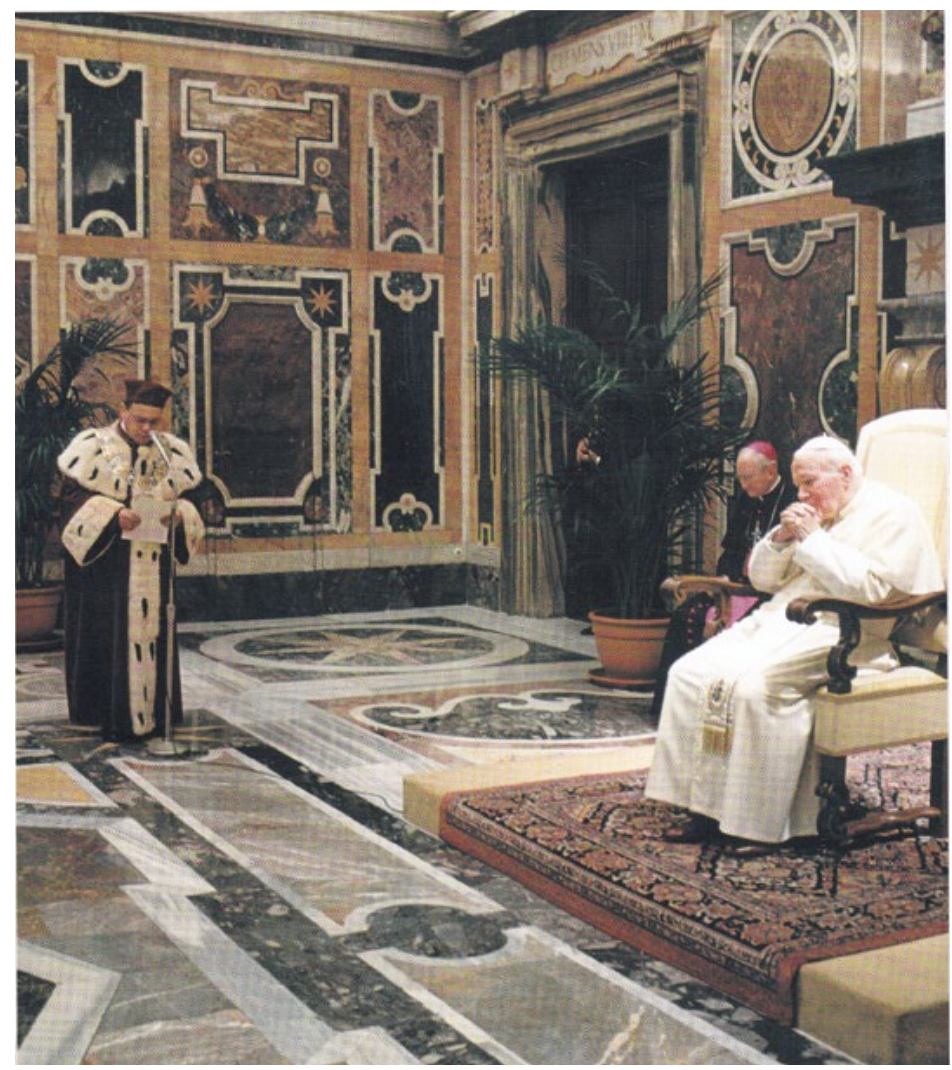

fot. Servizio Fotografico de "L'O.R." 00120 CITTA DEL Vaticano

\section{Laudation of Professor Włodzimierz Kluciński, PhD, Rector and the Holy Father's doctoral advisor}

Your Holiness, Beloved Holy Father!

Representatives of the academic community of the Warsaw University of Life Sciences together with their guests, including Prelate Tadeusz Wojdat, the parish priest of the Church of the Transfiguration in Ursynów in Warsaw, located in the park bearing Your Holiness' name and Fr Ryszard Bosakowski OP, the university chaplain, have come to the Holy See to express their love and deep respect for You, Your Holiness.

We are experiencing today a unique, in its historic dimension, day in our 186-year tradition since we are another Polish university, and the first university 
of agriculture, which has the honour to award You, Your Holiness, the supreme moral authority of the contemporary world, and a fellow countryman, the degree of doctor honoris causa.

Your Holiness' consent to receiving the degree is an unparalleled event for our milieu and we treat it as your recognition of our achievements to date.

The Warsaw University of Life Sciences dates back with its tradition to the first half of the $19^{\text {th }}$ century. It was founded as the Institute of Agronomy, during the Partitions of Poland, with the initiative of Stanisław Staszic and Stanisław Potocki, as an expression of love and care for the homeland, concern about the development of agriculture, and respect for Polish soil.

Throughout its history, its faculty members and graduates have been active participants of scientific, economic, social and political life. For example, one cannot mention Professor Władysław Grabski, the rector, a renowned economist, the creator of the Polish currency, twice prime minister and minister of treasury and agriculture; or Professor Józef Mikułowski-Pomorski, minister of agriculture, minister of the religious denominations and public enlightenment, the first rector of the Warsaw University of Life Sciences.

Allow me also to highlight the commitment of faculty members and students of our university in setting up the $36^{\text {th }}$ Infantry Regiment of Academic League in 1918 and its participation in the defence of our homeland in 1920 and $1939^{1}$.

The contemporary Warsaw University of Life Sciences is an academic school which has trained more than 55,000 graduates. At the moment, there are approximately 17,500 students pursuing their programmes in 21 fields while the university employs 1,100 academic teachers.

Among the 62 honoris causa doctors there are, among others, Ignacy Mościcki, from 1926 to 1939the President of Poland, Cardinal Józef Glemp, the Primate of Poland, and Noble Prize winners: Norman E. Borlaug, Peter C. Doherty and Rolf M. Zinkernagel.

\section{Beloved Holy Father!}

Being aware of Your profound contribution to building the civilization of love in the world, the ethical foundation of not only humanities but also natural and technical sciences, the Senate of Warsaw University of Life Sciences, on the request of all eleven Faculty Boards, had the honour to pass on 17 December

1 These two dates mark two important moments in the history of Poland. The first - the Polish-Soviet War, the other - the Nazi Germany invasion of Poland and the beginning of the Second World War [translator's footnote]. 
of the first year of the new millennium a resolution and proclaim Your Holiness an honoris causa doctor of its Alma Mater.

Listening intently for more than 23 years to the words of Your Holiness, the most eminent representative of humanities, a theologian and philosopher, by awarding this degree we would like to say our gratitude for all the good we receive from Your pastoral teaching.

We thank You for showing humankind the need of getting united into one common world family of all nations on the globe, whatever their political and religious beliefs, in the name of Christ's commandment "Love one another."

We thank You, Your Holiness, for Your care about the proper development of academic institutions, for showing academic milieus the ways leading to finding out the truth and the need to serve that truth in the social dimension in line with the content of your encyclical letter Veritatis Splendor, and for recommendations on how to shape properly the personality of young people.

An inherent part of Your teaching is pointing at the need of a dialogue between intellectual cognizance and faith. The beginning words of Your encyclical letter Fides et Ratio have been deeply rooted in us:

"Faith and reason are like two wings on which the human spirit rises to the contemplation of truth; and God has placed in the human heart a desire to know the truth - in a word, to know himself - so that, by knowing and loving God, men and women may also come to the fullness of truth about themselves."

We thank You, Your Holiness, also for that part of Your pastoral teaching that demonstrates to young people of the whole world, including academic youth, a need to live in love, truth and faith so that in their pursuit to explore the secrets of science, they will remember the fundamental requirements "of social love, of respect for the rights of others - for every man, nation and people." Beloved Holy Father!

The academic community of an agricultural university cannot abstain from thanking You, Your Holiness, for Your care about rural Poland and the dignity of people living there, as well as for Your care and teaching connected with life and work, including hard but dignified farm work.

2 John Paul II, Encyclical Letter Fides Et Ratio, opening words, see: http://w2.vatican.va/ content/john-paul-ii/en/encyclicals/documents/hf_jp-ii_enc_14091998_fides-et-ratio.html (12.04.2019).

${ }^{3}$ Cf. John Paul II, Encyclical Letter RedemptorHominis, 15, see: http://w2.vatican.va/ content/john-paul-ii/en/encyclicals/documents/hf_jp-ii_enc_04031979_redemptor-hominis. html (12.04.2019). 
An important signpost for us is Your teaching included in the encyclical letter Laborem Exercens and the words addressed to Polish farmers during your pilgrimages to Poland.

Memorable are Your words, Your Holiness, addressed to farmers during Your homily in Niepokalanów:

"Be God's crop! Stay with love at this farmland, at this mother and breadwinner of yours. (...)This earth bears "thorn and thistle," but thanks to your work it bears food, bringing bread to man. This is a special source of dignity of farming. Your dignity."

Beloved Holy Father!

One of the tasks of our university is to educate and do research into the aspects connected with life and work of a rural family and family farms. Therefore, we listen intently to all themes of Your teaching, Your Holiness, connected with strengthening the family with the truth of the Gospel.

We are making an in-depth analysis of the thoughts included by You, Your Holiness, in the encyclical letter Evangelium Vitae, the apostolic exhortation Familiaris Consortio, and in many addresses published under a common title Man and Woman He Created Them. ${ }^{5}$

Thank You, Your Holiness for Your empathy with the problems of Polish society, your acting for the good of the Polish cause and for Your care so that Poland will meet the civilization challenges it faces.

Beloved Holy Father!

The academic community of the Warsaw University of Life Sciences, strengthened by today's ceremony and by including You, Your Holiness, into its members, will uphold, with determination, the truth and will shape a righteous conscience, serve good and basic humankind values, and within its capabilities will influence an appropriate development of Polish farming and rural Poland.

In our teaching and scientific activities, we will always strive to accomplish our mission as an academic institution being the conscience of the nation.

In our daily work, we want to fulfil Your Holiness' words, and share with students, not only our store of scientific knowledge. but also with the richness of our humanity. We want to be professors who are true masters and guides for

${ }^{4}$ John Paul II's homily during the Mass in Niepokalanów on 18 June 1983 during the Pope's second pilgrimage to Poland, see: https://ekai.pl/dokumenty/homilia-w-czasie-mszysw-niepokalanow/(Polish text) (12.04.2019).

${ }^{5}$ John Paul II, Man and Woman He Created Them: A Theology of the Body, transl. Michael Waldstein, Boston 2006. 
academic youth. Let us put more effort to live and work in the light of the truth and counteract all forms of evil.

Your Holiness!

A ceremony of awarding an honoris causa doctorate is traditionally accompanied with the song that begins with the words:

"Gaude, Mater Polonia, prolefaecundanobili/Rejoice, oh Mother Poland, Rich in noble offspring."

While granting You today, Your Holiness, this diploma, we are saying:

"Omnisgaude terra mater, proleshabereillustres, nobilesque/Rejoice, oh Mother Land, as You have an eminent son."

I ask Your Holiness for a blessing for the whole academic community of Warsaw University of Life Sciences and for a blessing for its further development.

I kindly ask Your Holiness to accept an honoris causa diploma of Warsaw University of Life Sciences.

Another point of the ceremony was my conferral of the diploma in Latin on behalf of the whole academic community of Warsaw University of Life Sciences, and - in accordance with the tradition - a student's cap. This part of the ceremony was accompanied by Gaude Mater Polonia hymn performed by "Promni" ensemble.

The highlight of the ceremony was the address of His Holiness John Paul II:

\section{The address of His Holiness John Paul II}

Dear Ladies and Gentlemen,

I cordially welcome all: the Senate, professors, faculty members and administrative staff, students and the choir. I address a special welcome to $\mathrm{Mr}$ Rector together with my thanks for the words he addressed to me.

I am glad that I can host you as representatives of the multi-thousand academic community of Warsaw University of Life Sciences.

Thank you for arriving in Rome to experience, together with the Pope, this university ceremony. It should be rather said that 'around the Pope' as you in your kindness and goodness wanted to award him an honoris causa doctorate of your university. I must admit that the focus of your attention on my person would be quite embarrassing were not the understanding that you rather come to the Successor of St. Peter to express, through your closeness, a deep bond 
that connects your university with the Christian cultural tradition of the Polish nation and the whole Europe. I know that you would also like to express this continuous search for this unity that is achieved on a higher, as it were, metaphysical level - the unity between science and faith. Therefore, I welcome you with joy and gratitude.

The Warsaw University of Life Sciences can pride itself of a long and rich tradition going back to the painful period of the Partitions of Poland, hopes connected with the Enlightenment and with social and educational activity of such persons as Stanisław Staszicor Stanisław Potocki. It is just them who gave rise to the institution, that through robust scientific and educational work, was supposed, not only to contribute to the development of farming, but also to evoke in the nation, its love and respect for Polish soil, as well as for the historical and cultural heritage connected with it.

For decades, amid changing fortunes of the domestic history, your university has been a resilient centre of scientific, economic, social and political life. It is here where eminent scientists, politicians but also heroes who fought for independence of the homeland studied and taught. This school was indeed a lively source of love for the Polish soil and care about the fate of rural Poland and the whole homeland.

Your presence, which connotes this beautiful tradition, at the same time refers to the present day. It demands, somehow, to ask what the role of Warsaw University of Life Sciences may be in today's Polish social and economic realities. While looking for an answer to this question, first of all, it has to be observed that today we are witnessing a deep crisis of Polish farming which is the consequence of the erroneous ideology and practices followed in previous decades, causing delays in comparison with modern European farming, for many years supported by state subsidies. The economic crisis of the rural area has consequences also on the level of national culture. Since many young talented people, coming from the country, for economic reasons, cannot continue their education in secondary schools and schools of higher education, undoubtedly this must result in the spiritual impoverishment not only of rural Poland but of the whole society. The issue of the rural area has another painful dimension: A contemporary Polish farmer seems to suffer not only from a lower profitability of their hard work and, what is connected with it, a shortage of funds to develop their farm, but also from a lack of social respect for their hardship and a lack of support in their efforts to change the situation. This attitude of some political and social environments may, in turn, stem from a decline of the sense of value 
of the family and home soil, moving away from multi-century spiritual traditions connected with it, snuffing out the love for that soil that for centuries has been sprinkled with the sweat and blood of our ancestors.

In this context, the role of Warsaw University of Life Sciences seems to be indispensable. It is known that today you are undertaking new tasks in line of the spirit of the time and requirements posed by the development of sciences as well as the cultural, economic and social changes. I know that your university education covers more than fifty specializations. Surely, many of them are not directly related to agriculture or to a wide array of phenomena connected with living in the country. However, it is important that you do not forget about the roots and tradition that demanded from all who were part of your university community to care for the development of the rural area and to raise love towards the Polish soil-breadwinner. Please persevere in the hardship of building scientific foundations for the development of rural Poland, and broadening perspectives of its cultural and spiritual growth. But, first and foremost, please be persistent in giving, to all urban and rural dwellers, a testimony of love and respect that is owed to Polish soil and to all who, by the sweat of their brow, steward it. Do whatever you can so that rural Poland may join the structures of the united Europe with dignity, affluence and rich in spirit.

In this hardship, I will support you with my prayer and heartfelt thought. Once again, thank you for your presence. I wish you all success in your work in favour of science, culture and social life. Please take my greetings to the many thousand students and professors of your university. God bless you!

When the Holy Father finished his speech, I was asked to sit next to him and introduce, one by one, all the participants of the ceremony. The individual meetings were accompanied with carols and folk songs sung by "Promni" ensemble. The ceremony ended with a photograph of the Holy Father, first taken with "Promni" and then with all participants of the audience.

John Paul II was leaving Clementine Hallwith the words of the folk song Góralu czy ci nieżal? (Highlander do you not regret) ${ }^{6}$ sincerely saluting all participants and bidding them goodbye.

A moment which was exceptionally moving and remains imprinted in my mind were the Holy Father's words said at the end of the audience, reminding

${ }^{6}$ See the translation of the lyrics of the song, one of the Pope's favourite: https:// lyricstranslate.com/pl/goralu-czy-ci-nie-zal-highlander-do-you-not-regret.html (15.04.2019) [translator's footnote]. 
Professors Elżbieta Biernacka and Tomasz Borecki, Deputy Rectors, Rev. Tadeusz Wojdat and Fr Ryszard Bosakowski OP and myself and my wife of an invitation to dinner in the Pope's private apartments. At dinner, the Holy Father was accompanied by Bishop Stanisław Dziwisz, Rev. Mieczysław Mokrzycki and Rev. Paweł Ptasznik. The dinner, which lasted more than two hours, was an exceptional opportunity for the Holy Father to reveal himself as a man who cares about the academic and the spiritual growth of Polish youth.

The following ceremonies held in successive years are a proof of the lasting memory of the Holy Father John Paul II among the academic community of Warsaw University of Life Sciences:

- unveiling of the commemorative plaque in the hall of the Rector's Palace at the first anniversary of awarding the Holy Father an honorary doctorate (11 January 2003),

- a mourning sitting of the University Senate and Faculty Boards dedicate to the late John Paul II (5 April 2005),

- a field Mass dedicated to the late John Paul II (6 April 2005),

- a ceremony of planting an oak tree in memory of John Paul II at the university campus (18 May 2006),

- celebrations of the $10^{\text {th }}$ anniversary of awarding John Paul II an honoris causa doctorate of Warsaw University of Life Sciences:

- a seminar held on 11 January 2012 at the university, during which two lectures were delivered. The first by Rev. Professor Krzysztof Pawlina entitled John Paul II - A Teacher and Visionary. The Future of JP2 Generation and the second by Professor Franciszek Ziejka entitled John Paul II - A Man of University.

- a Pontifical Mass celebrated on 15 January 2012 in the Church of the Ascension of Christ in Warsaw together with the deposition of Blessed John Paul II's relics in the Chapel of Apostles.

- joint symposiums of the Warsaw University of Life Sciences and the Cardinal Stefan Wyszyński University in Warsaw on the occasion of the canonization of John Paul II (2-3 April 2014). 